\title{
Clusters of opportunity: results of research on educational effects of participation in the project "School for High School Students"
}

\author{
Elena Ivanova $^{1 *}$, Irina Vinogradova $^{1}$, Elizaveta Mayakova ${ }^{1}$, Ekaterina Barsukova $^{1}$, and \\ Anna Ter-Grigorian ${ }^{1}$ \\ ${ }^{1}$ Moscow City University, Institute of System Projects, Laboratory of Educational Infrastructures, \\ Moscow, Russia
}

\begin{abstract}
The objective of the research presented in this article is to study the opportunities for students, teachers, and administrative teams to take part in the project "School for High School Students". The main research method is a survey conducted among students, teachers, and administrations of educational institutions of the city of Moscow taking part in the project "School for High School Students". The survey data were analyzed with the help of content analysis (text analysis based on Zipf's law). The data obtained as a result of the sampling of schools that were taking part in the project "School for High School Students" were analyzed in terms of opportunities for the main participants of educational relations. Substantive and infrastructure changes in the projects provide possibilities: for high schoolers - in terms of creating individual educational routes, forming a subjective position, professional and personal self-determination, trying out their potential profession, and choosing their career path; for teachers - in terms of professional development, acquiring new methodological experience, using new teaching frameworks, gaining experience of working with new equipment and electronic resources; for administrative teams - in terms of improvement of the quality of conditions, process, result, and management, namely, improvement of the school status, positive dynamics of students' educational results, resourcing of the project, forming a motivating learning environment and environment for occupational trials, and networking interactions with educational and other organizations.
\end{abstract}

Keywords: opportunities, Moscow School for High School Students, educational environment.

\section{Introduction}

One of the crucial tasks of the education system in Moscow is to create a new educational environment for school students allowing them not only to gain relevant knowledge and master the skills that will help them choose their careers in the future and become professionals in their sphere but also to become creators of their own educational routes and

* Corresponding author: ivanovaev@mgpu.ru 
pursue self-determination in the chosen subject and inter-subject field [1]. This task is substantively addressed by the project "School for High School Students" oriented at the formation of an integrated educational space at the level of general secondary education to improve the motivation of school students and implement their individual educational routes, which suggests the need for usage of new educational forms and technologies and changes in the structure of the educational process and infrastructure in general [2].

Substantive and infrastructure changes taking place due to the project "School for High School Students" determine in a set of opportunities for students' personal and professional self-determination, trying out their potential professions at the level of general secondary education, and creation of conditions for the professional development of teachers. School represents one of the important contexts within the framework of which students' identity is formed. Despite numerous theoretical discussions and empirical research in the sphere of psychology and education, there is a clear knowledge gap about the impacts of school environments on adolescent identity formation [3]. School spaces should provide students with opportunities to take risks, build authentic encounters with the world around them, and foster skills for lifelong learning in a changing and uncertain world [4].

\section{Methods}

In this work, we attempted to explore the opportunities offered by the project "School for High School Students" from the perspective of the main participants of educational relations. For this purpose, we used the method of survey. The respondents that took part in the survey included 84 high school students, 54 teachers, and nine representatives of three educational institutions of the city of Moscow implementing the project "School for High School Students".

The obtained data were processed with the help of content analysis. The responses given by students, teachers, and representatives of administration were used as the text for content analysis. The usage of content analysis allowed us to identify the main factors that determine the opportunities offered by the project "School for High School Students" from the perspective of the main participants of educational relations.

\section{Results and discussion}

What opportunities offered by the project "School for High School Students" do the participants of educational relations see? We will try to answer this question by analyzing the responses given by the students, teachers, and administrations of schools taking part in the project.

Opportunities for students:

What are the new opportunities for students provided by the project "School for High School Students"?

The data resulting from content analysis are visualized in Figure 1.

As it can be seen from Figure 1, the most common categories mentioned in the students' responses included action words, such as to receive, learn, study, choose, define, get, development, and expand. The identified fact characterizes the subjective position of students, who stop treating themselves only as objects of educational influence and start acting as subjects [5]. A self-determining person is a subject who realizes what they want, what they are, what they can, and what is expected of them by their community and society $[6,7]$. Therefore, "a subject of educational practice (should have) an opportunity for experiment and a purposefully organized trial in relation to the content represented in the 
educational space and, among other things, to the very educational space as a social one" [8].

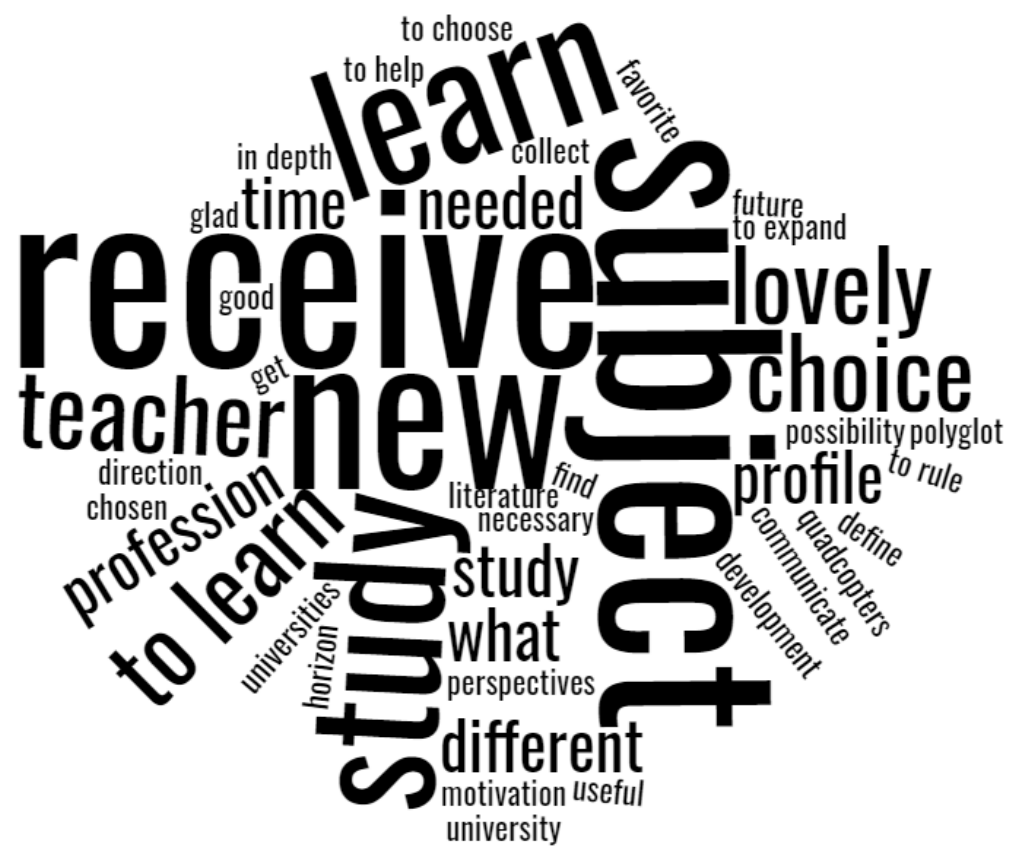

Fig. 1. The cluster of opportunities for students offered by the project "School for High School Students".

Answering the question about the opportunities offered by the project, the students indicated:

- substantive changes (the emphasis was placed on enhancing the content of education and deeper studies of certain academic disciplines, as well as the opportunity to make a fast switch from theory to practice),

- infrastructure changes (equipment, technical infrastructure, IT). The school environment influences learners in terms of their behavior and achievements. If students are satisfied with the school space, this can be an advantage, as it can motivate them to do activities in the school [9] support the development of children's creativity [10],

- staffing conditions. The main focus here was on the expertise of teachers interested in their subjects. The quality of interaction between the teacher and students determined by the teacher's qualification can become the main factor of students' success and the quality of education in general [11].

These changes provide high school students with an opportunity to make a real choice.

The next important factor that stands out from the obtained responses is connected with the category of "Interest":

- students feel interested during classes, which can be considered a manifestation of internal motivation, namely, cognitive motivation. Internal motivation is a reliable indicator that distinguishes competent and successful students [12];

- construction of the educational process taking into account the interests of students, which implies individualization of the educational process, resulting in improvement of achievement of educational results. Talking about individualization of education more substantively, the focus should be placed on the creation of conditions in high school for undertaking different types of trials (presence of corresponding "trial" modules) and 
development of individual module sets — "standardized packages" (for example, profile classes), as well as individual educational routes. Such examples can be found in the Voss school (Norway) [13];

- self-determination. In this respect, the project "School for High School Students" creates the conditions and resources encouraging the formation of students' readiness for self-determination.

The students also pointed out the opportunity to interact with higher education institutions. These data correlate with the results of studies of parental attitudes about education in the city. Thus, in the future most parents see their children having a higher education and strive to ensure that during studing at school children prepare for entering to university [14]. For instance, some of the major subjects were taught by invited university teachers and students. Interaction with them is also a significant aspect of opportunities offered by the project "School for High School Students", which leads to an increase in the time frame for socializing and expanding the corresponding social space.

Within the project "School for High School Students", there are such profile classes as "Engineering class", "Medical class", and "IT class", requiring the creation of technological infrastructure and a modern educational space (classroom furniture, transformation of the school space, etc.) to implement these learning objectives. The students also mentioned that "it is convenient to work with the equipment" and there is "an opportunity to try their hands" and "an opportunity to use theoretical material in practice" and "see everything in reality and understand the topic".

Opportunities for teachers

The teachers looked at the field of opportunities offered by the project "School for High School Students" from the perspective of their role (Fig. 2). The role performed by teachers is changing: they do not only present knowledge to students but also become tutors, learning technologists, and mentors in terms of professional self-determination [15].

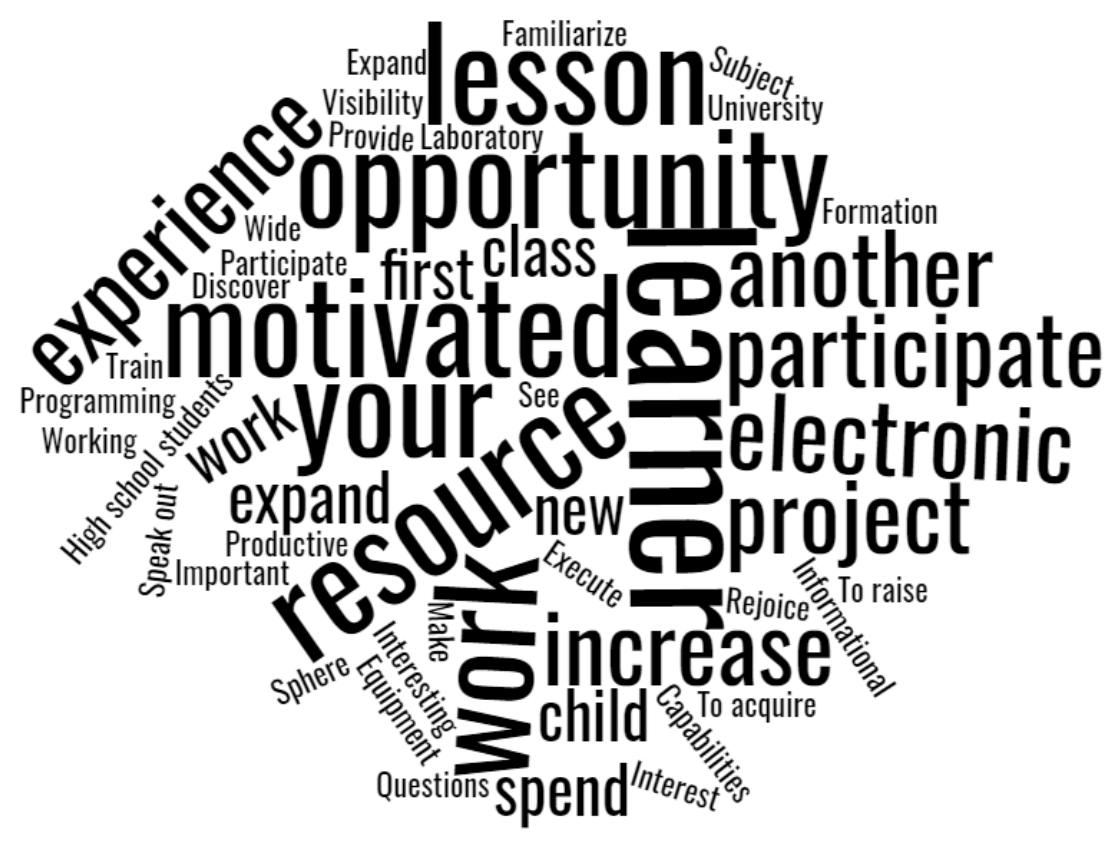

Fig. 2. The cluster of opportunities for teachers offered by the project "School for High School Students". 
The responses given by the teachers suggest that they saw the following opportunities:

- working with motivated students,

- professional development, acquiring new methodological experience, using of new working formats (intensive courses, immersions, educational events, trainings, and projects), and experience of working with new equipment and electronic resources,

- cooperation with higher education institutions and other educational organizations. The majority of research and project works are carried out by students based on resource centers within research and development centers and higher education institutions.

Opportunities for administrative teams:

From the perspective of a manager, the opportunities offered by the project involve improvement of the quality of conditions, process, result, and management.

The administrative teams saw the following opportunities arising from participation in the project (Fig. 3):

- implementation of networking projects at the level of city or district and positioning of educational organizations in the educational space of the city,

- enhancing field-specific education,

- cooperation with higher education institutions and other educational organizations with the assistance of invited university students and school graduates,

- usage of new formats of distance and digital learning and formation of a motivating learning environment that encourages professional trials,

- providing the project with all necessary resources and equipment (access to laboratories and technical complexes in the framework of the organization of high schoolers' project and research work and infrastructure changes of the educational environment),

- achievements in contests, olympiads, and conferences.

Infrastructure changes of the educational environment within the project "School for High School Students" involved the solution of a few tasks from the perspective of administrative teams:

- firstly, the equipment of the building with technological facilities and reinterpretation of the functions performed by the school premises that are not actively involved in educational and social processes allows creating the necessary space for professional trials. An illustration of such solution is the renovation of the outdated assembly hall or gym and creating there an IT area differentiated by professional directions: system administration, programming, robotic engineering, and software development for mobile devices (Fig. 4),

- secondly, creating areas for social development and independent project activity: recreation areas, media laboratories, enhanced libraries, and large open space classes and lecture halls with the necessary equipment and mobile furniture (Fig. 5). Such areas encourage the development of communicative and presentation skills and allow students to establish social relations outside their class and improve their social responsibility and the ability to evaluate their own actions and results adequately [16]. 


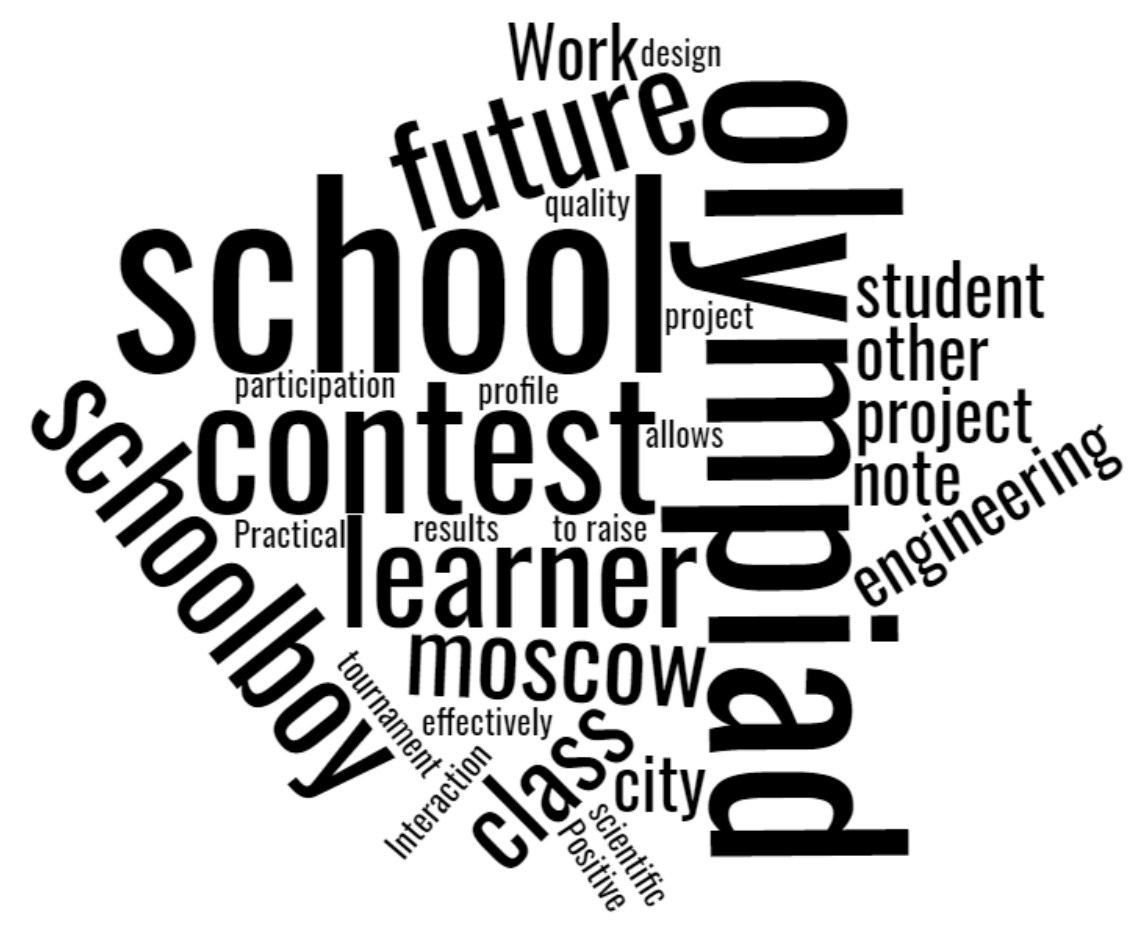

Fig. 3. The cluster of opportunities for administrations of schools offered by the project "School for High School Students".

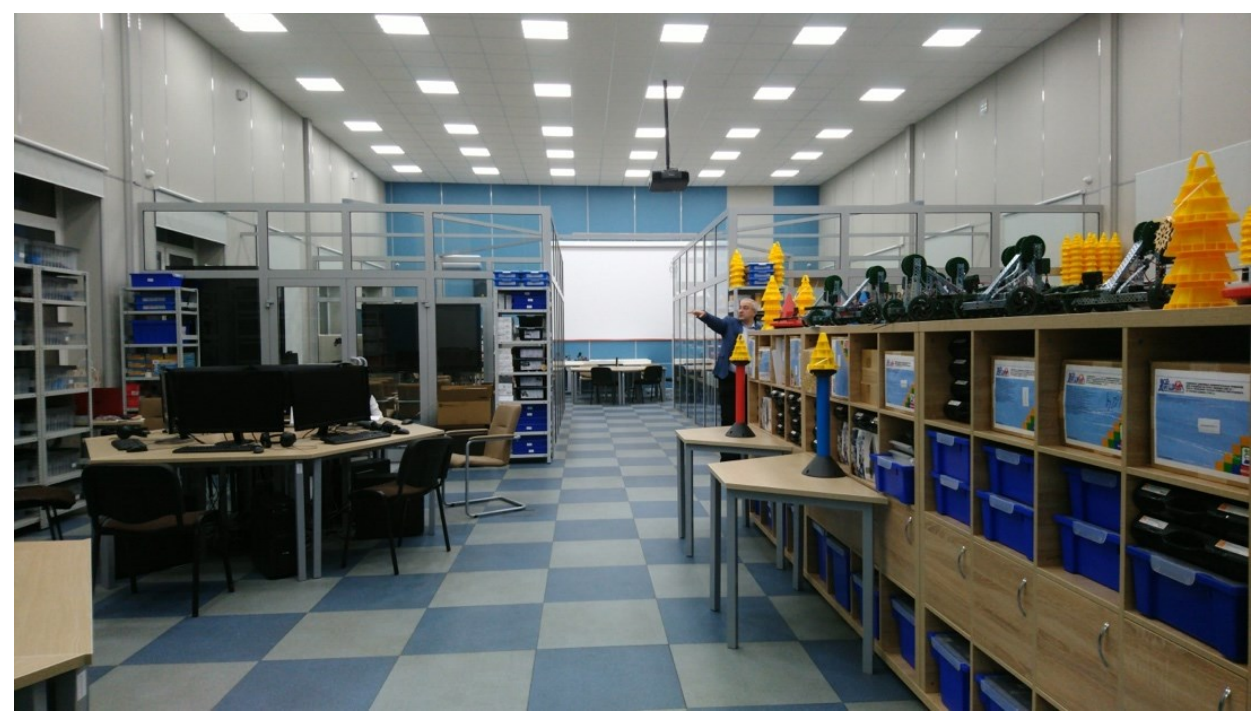

Fig. 4. Assembly hall area rebuilt into an IT area designed for the needs of various technologically advanced jobs. 


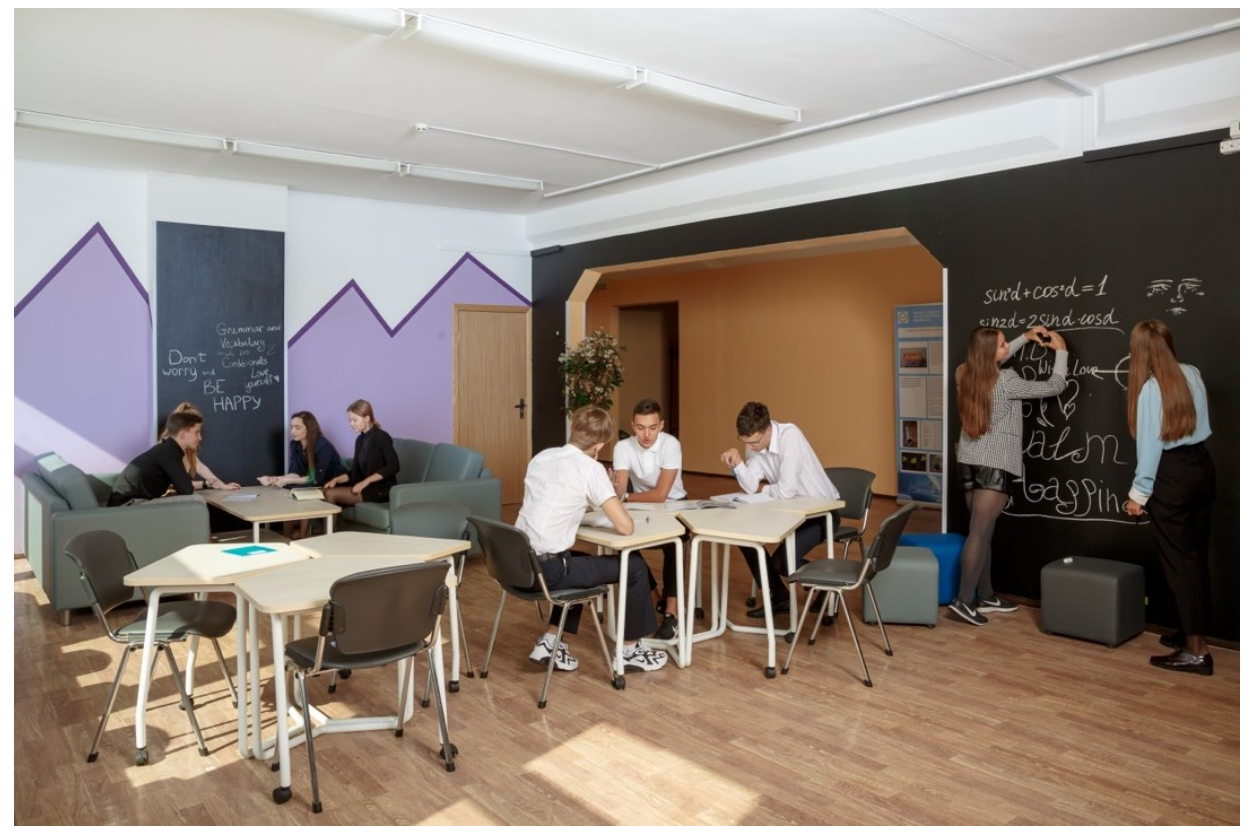

Fig. 5. Recreation area equipped for independent project work conducted by high school students.

Infrastructure changes in schools provide high school students with opportunities for independent activities, as well as setting goals and achieving them. Such changes suggest a high degree of freedom in choosing the elements of educational routes [17].

\section{Conclusion}

Substantive and infrastructure changes introduced within the project "School for High School Students" created the following opportunities:

- for students: in terms of formation of a subjective position, creating individual educational routes, professional and personal self-determination, trying out their potential profession, a real choice of future career paths, and effective preparation for entering specialized higher education institutions,

- for teachers: in terms of professional development, acquiring new methodological experience, using new teaching frameworks, gaining experience of working with new equipment and electronic resources, and working with motivated students,

- for administrative teams: in terms of improvement of the quality of conditions, process, result, and management, namely, improvement of the school status, positive dynamics of students' educational results, resourcing of the project, formation of a motivating learning environment and environment for occupational trials, and networking interactions with educational and other organizations.

\section{Acknowledgments}

The publication was prepared within the scientific research work "Monitoring of the effectiveness of the project for high school in general secondary education" conducted by the State Autonomous Educational Institution of Higher Education "Moscow City University" under a state assignment in 2019-2020. 


\section{References}

1. E. Malevanov, A. Adamskii, A. Asmolov, I. Frumin, A. Soloveichik, I. Remorenko, M. Rakova, A. Semenov, I. Abankina, A. Margolis, Obrazovatelnaya politika, 2(82), 8-17 (2020)

2. E.V. Ivanova, I.A. Vinogradova, S.A. Zadadaev, Obrazovanie i nauka, 21(7), 69-89, (2019). https://doi.org/10.17853/1994-5639-2019-7-69-89

3. N. Abbasi, Adolescent Identity Formation and the School Environment: The Translational Design of Schools, in The Translational Design of Schools. Advances in Learning Environments Research, 81-103 (Sense Publishers, Rotterdam, 2016)

4. T. Rooney, Planning for Flexible and Innovative School Spaces: Safety and Risk, in Risk, Protection, Provision and Policy, 405-421 (Springer, Singapore, 2017)

5. N.A. Kulikova, Starsheklassnik kak subekt uchebnoi deyatelnosti [High schooler as a subject of educational activity], in Nauka i innovatsii v XXI veke: aktualnye voprosy, otkrytiya i dostizheniya, Collection of articles of the 4th International Scientific Conference, 5 June 2017, Penza, Russia (2017). Accessed on: December 20, 2020. [Online]. Available: https://www.elibrary.ru/item.asp?id=29268038\&pf=1

6. A.V. Luchenkov, Voprosy obrazovaniya, 1, 191-202 (2016)

7. P.A. Sergomanov, A.V. Luchenkov, N.P. Vasileva, N.F. Loginova, Vozrastnoorientirovannaya starshaya shkola. K realizatsii novykh obrazovatelnykh standartov [Age-oriented high school. To implementation of new educational standards] (Lenand, Moscow, 2014)

8. D.S. Popov, Yu.A. Tyumeneva, Yu.V. Kuzmina, Voprosy obrazovaniya, 4, 30-52 (2010)

9. S. Mokhtarmanesh, M. Ghomeishi, Sustainable Cities and Society, 51, 101762 (2019). https://doi.org/10.1016/J.SCS.2019.101762

10. M. Galewska-Kustra, Creativity Theories - Research - Applications, 3(1), 84-93 (2016). https://doi.org/10.1515/ctra-2016-0006

11. McKinsey\&Company, In-depth Analytics (n.d.). Accessed on: December 20, 2020. [Online]. Available: https://www.mckinsey.com/ru/our-insights\#

12. T.O. Gordeeva, O.A. Sychev, E.A. Shepeleva, Voprosy psikhologii, 1, 15-26 (2015)

13. Voss High School, Accessed on: December 20, 2020. [Online]. Available: https://www.facebook.com/NYE-Voss-vidareg\%C3\%A5ande-skule955386404500152/

14. I.V. Vachkov, S.N. Vachkova, M.V. Voropaev, Psikhologicheskaya nauka i obrazovanie, 24(3), 19-31 (2019). https://doi.org/10.17759/pse.2019240302

15. V.A. Lvovskii, T.Yu. Mysina, E.G. Ushakova, Bulletin of Moscow City University, Series: Pedagogy and Psychology, 2(44), 31-41 (2018)

16. T. Makëla, S. Helfenstein, Learning Environments Research, 19(3), 411-440 (2016). https://doi.org/10.1007/s10984-016-9214-9

17. E.V. Ivanova, E.M. Barsukova, Metodist, 6, 6-14 (2019) 